\title{
Spinal cord ischemia following thoracotomy without epidural anesthesia
}

\author{
[Ischémie de la moelle épinière à la suite d'une thoracotomie sans anesthésie \\ péridurale]
}

Aeyal Raz MD PhD, ${ }^{*}$ Aharon Avramovich MD, ${ }^{*}$ Efrat Saraf-Lavi MD, $†$ Milton Saute MD, $\ddagger$ Leonid A. Eidelman MD*

Purpose: Paraplegia is an uncommon yet devastating complication following thoracotomy, usually caused by compression or ischemia of the spinal cord. Ischemia without compression may be a result of global ischemia, vascular injury and other causes. Epidural anesthesia has been implicated as a major cause. This report highlights the fact that perioperative cord ischemia and paraplegia may be unrelated to epidural intervention.

Clinical features: A 7I-yr-old woman was admitted for a left upper lobectomy for resection of a non-small cell carcinoma of the lung. The patient refused epidural catheter placement and underwent a left T5-6 thoracotomy under general anesthesia. During surgery, she was hemodynamically stable and good oxygen saturation was maintained. Several hours following surgery the patient complained of loss of sensation in her legs. Neurological examination disclosed a complete motor and sensory block at the T5-6 level. Magnetic resonance imaging (MRI) revealed spinal cord ischemia. The patient received iv steroid treatment, but remained paraplegic. Five months following the surgery there was only partial improvement in her motor symptoms. A follow-up MRI study was consistent with a diagnosis of spinal cord ischemia.

Conclusion: In this case of paraplegia following thoracic surgery for lung resection, epidural anesthesia/analgesia was not used. The MRI demonstrated evidence of spinal cord ischemia, and no evidence of cord compression. This case highlights that etiologies other than epidural intervention, such as injury to the spinal segmental arteries during thoracotomy, should be considered as potential causes of cord ischemia and resultant paraplegia in this surgical population.
Objectif : La paraplégie est une complication rare mais dévastatrice de la thoracotomie, causée habituellement par la compression ou l'ischémie de la moelle épinière. L'ischémie sans compression peut résulter de causes diverses dont une ischémie générale ou une lésion vasculaire. Alors que l'anesthésie péridurale est vue comme cause majeure, notre article souligne que l'ischémie médullaire périopératoire et la paraplégie n'y sont peut-être pas reliées.

Éléments cliniques : Une femme de 7 I ans a subi une lobectomie supérieure gauche pour la résection d'un carcinome pulmonaire non à petites cellules. Elle a refusé la mise en place d'un cathéter péridural et a subi une thoracotomie en T5-6 sous anesthésie générale. Pendant l'opération, l'hémodynamique a été stable et une bonne saturation du sang en oxygène a été maintenue. Quelques heures après l'opération, la patiente a éprouvé une perte de sensibilité aux jambes. L'examen neurologique a révélé un bloc moteur et sensitif complet débutant à T5-6. L'imagerie par résonance magnétique (IRM) a montré une ischémie de la moelle épinière. La patiente a reçu un traitement stéroïde iv, mais est demeurée paraplégique. Cinq mois après l'opération, il n'y avait qu'une amélioration partielle des symptômes moteurs. Un examen d'IRM de contrôle confirmait le diagnostic d'ischémie de la moelle épinière.

Conclusion : Dans ce cas de paraplégie suivant une thoracotomie pour résection pulmonaire, ni l'anesthésie ni l'analgésie péridurales n'ont été utilisées. L'IRM a prouvé une ischémie de la moelle épinière et l'absence de compression médullaire. D'autres causes, comme la lésion des artères rachidiennes segmentaires pendant la thoracotomie, doivent être jugées susceptible de provoquer une ischémie médullaire suivie d'une paraplégie dans cette population chirurgicale.

From the Departments of Anesthesiology, ${ }^{*}$ Radiology; $\dagger$ and Cardiothoracic Surgery, $\ddagger$ Rabin Medical Center, Campus Beilinson, Petah Tikva, Israel.

Address correspondence to: Dr. Aeyal Raz, Department of Anesthesiology, Rabin Medical Center, Campus Beilinson, Petah Tikva,

49100, Israel. Phone: 972-3-9376850; Fax: 972-3-9376851; E-mail: eyalraz@clalit.org.il

Accepted for publication October 7, 2005.

Revision accepted January 30, 2006

Competing interests: None declared. 
$\mathrm{P}$ ARAPLEGIA is a rare but devastating complication associated with thoracotomy. Spinal cord ischemia is an important cause. Epidural anesthesia/analgesia has been implicated by several authors as a cause of spinal cord ischemia. ${ }^{1-3}$ Paraplegia not related to the use of epidural anesthesia has also been reported, and in many of these cases, cord compression resulting from surgical complications such as hemostatic material migration was found. ${ }^{4-7}$ In the case described below, paraplegia following thoracotomy was unrelated to either epidural intervention or cord compression. This report demonstrates that spinal cord ischemia following thoracic surgery may be related to factors other than anesthetic epidural intervention.

\section{Case report}

A 71-yr-old woman was admitted to hospital for a left upper lobectomy for resection of a non-small cell carcinoma of the lung. Her past medical history included heavy smoking and back pain. Cervical and lumbar degenerative disc disease had been documented several years previously. This was not accompanied by clinical evidence of myelopathy or radiculopathy. The patient also had a history of hypercalcemia, secondary to a parathyroid adenoma, complicated by nephrolithiasis and osteoporosis.

Epidural catheter placement was offered to the patient for the purpose of postoperative pain management; however, she refused and underwent a left T56 thoracotomy under general anesthesia. Anesthesia was induced with propofol, fentanyl and rocuronium, and was maintained with isoflurane $(0.8-1 \%$ endtidal concentration) in oxygen. Lung isolation was achieved with a 39-F left-sided double lumen tube (Mallinckrodt Medical, Athlone, Ireland). Tube location was verified with a flexible fibreoptic bronchoscope. During anesthesia which lasted $\mathrm{l}$ hr $45 \mathrm{~min}$, the patient remained hemodynamically stable, with systolic blood pressures between 110 and $160 \mathrm{mmHg}$. Oxygen saturation $\left(\mathrm{SpO}_{2}\right)$ values remained above $97 \%$ throughout the procedure. The duration of one-lung ventilation was about $60 \mathrm{~min}$. Following her uneventful left upper lobectomy, the patient's trachea was extubated in the operating room, and she was transferred to the postanesthesia care unit (PACU), where she received morphine $10 \mathrm{mg}$ iv for analgesia. During her PACU stay, the patient remained stable hemodynamically, with $\mathrm{SpO}_{2}$ values $>95 \%$.

Three hours after admission to the PACU, the patient complained of loss of sensation in her legs. Neurological examination revealed a fully awake, oriented patient with a complete motor and sensory

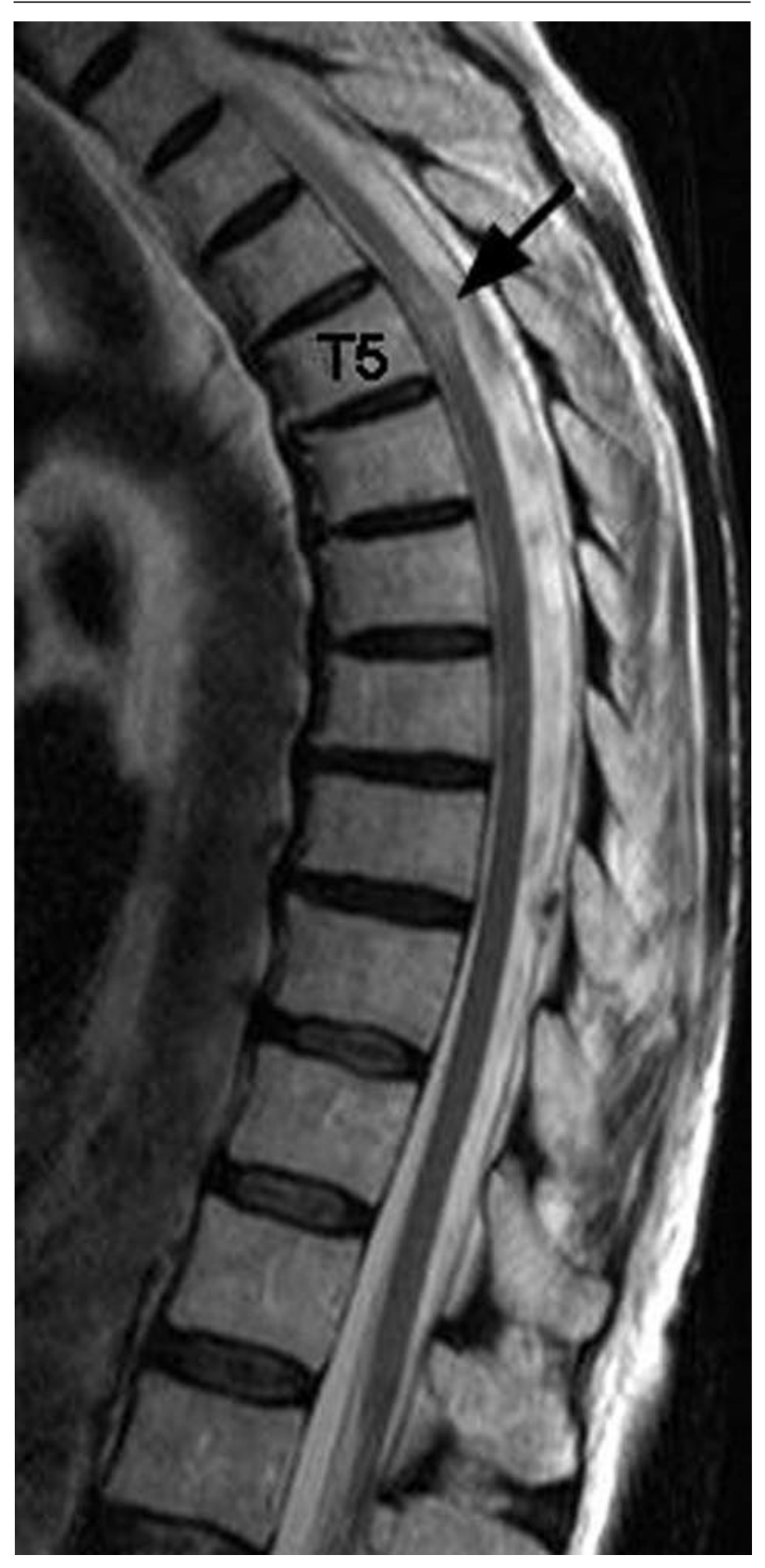

FIGURE 1 Magnetic resonance imaging of the thoracic cord performed several hours after the development of neurological deficit. This midsagittal T2-weighted image demonstrates a short segment of increased signal and cord enlargement at the T5 level (arrow), implying acute ischemia. 


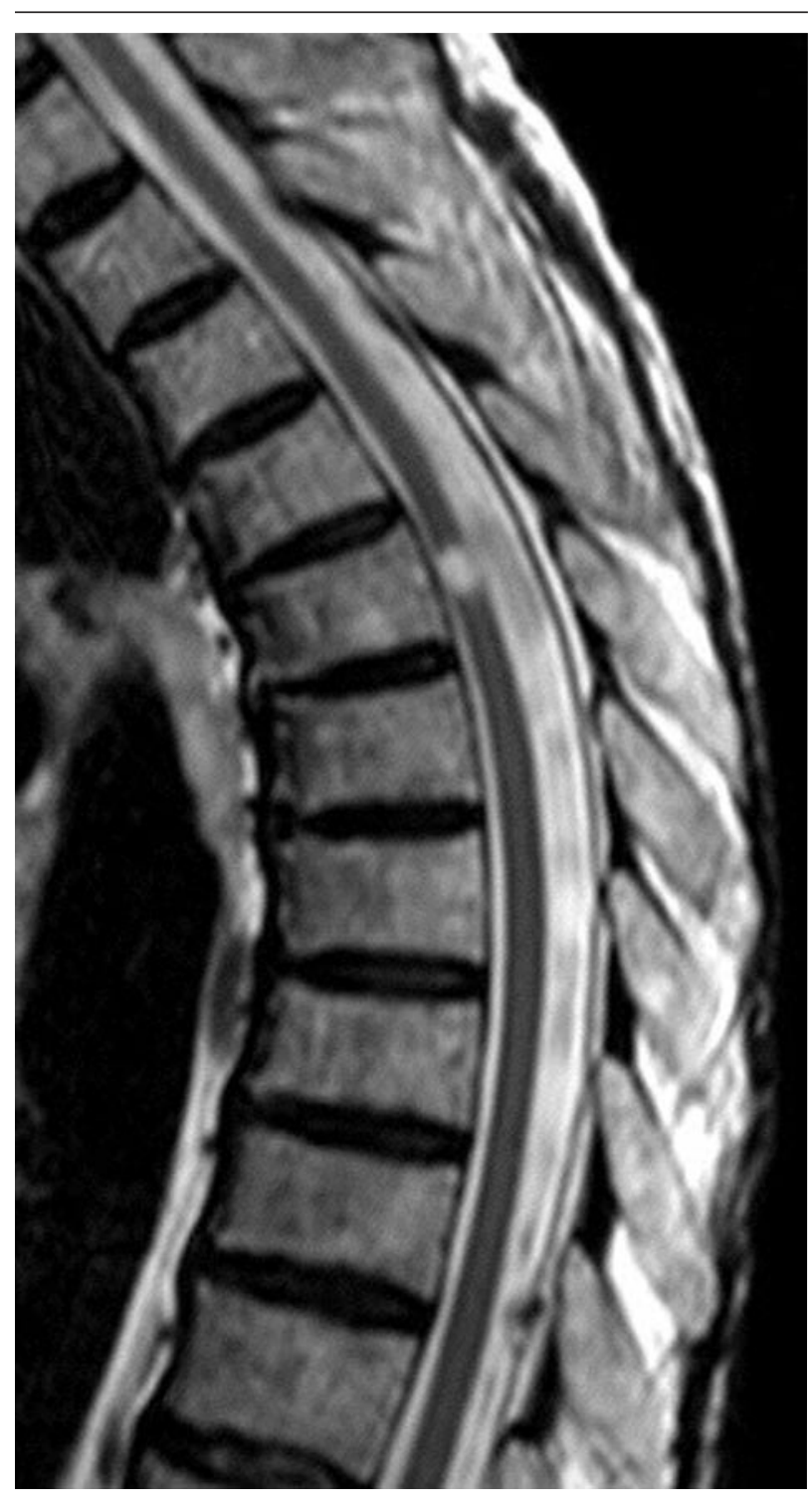

FIGURE 2 Five month follow-up magnetic resonance imaging. This midsagittal T2-weighted image shows focal cord atrophy and a hyperintense signal, indicating old ischemia.

block at the T5-6 level. Magnetic resonance imaging (MRI) of her thoracic spine showed focal cord enlargement at the T5 level, accompanied by a focal hyperintense signal on the T2-weighted images (Figure 1). The abnormal signal involved predominately the central grey matter, consistent with cord ischemia. Computerized axial tomography of the spine did not reveal any anatomical abnormalities.

We offered the patient cerebrospinal fluid drainage as a potential treatment, which she refused. She received dexamethasone $12 \mathrm{mg}$ iv tid, but remained paraplegic at the time of discharge, 23 days following her surgery. Neurological examination performed five months later revealed a slight improvement in motor findings, in that the patient was able to move the proximal muscles of her left leg. An MRI study at the same time revealed focal cord atrophy and evidence of myelomalacia (Figure 2).

This report was approved by the Institutional Ethic Committee, and did not require explicit patient consent according to Israeli law and the Institutional Ethics Committee guidelines.

\section{Discussion}

Paraplegia following thoracic surgery can be caused by complications of epidural anesthesia including an epidural hematoma, and possibly spinal cord ischemia, ${ }^{1,8}$ complications of surgery such as spinal cord compression from surgical oxidized cellulose that has migrated into the spinal canal, ${ }^{2,4-7}$ or ischemia of the spinal cord from other reasons. ${ }^{9-11}$ Spinal cord ischemia is a wellknown complication of thoracic aortic surgery and aortic cross clamping, with disruption of segmental arterial supply to the cord. ${ }^{2,9,12}$ Other potential factors include spinal cord procedures, spinal artery damage or embolization, coagulopathy, and global ischemia. ${ }^{9}$ In non-vascular thoracic surgery, however, spinal cord ischemia has been attributed to either cord compression or epidural anesthesia. ${ }^{1,3-5}$

Konstantinidou et al. reported a similar case of paraplegia following surgery in which epidural anesthesia was not performed. ${ }^{13}$ In their case, the most probable cause of spinal damage was intraoperative injection of chemotherapeutic drugs into the hepatic artery. ${ }^{14}$ The authors cautioned, as do we, that epidurals should not be implicated automatically as the cause of postoperative paraplegia, since this complication may ensue without epidural insertion or epidural drug administration.

Prior to widespread availability of MRIs, most clinical reports of spinal cord damage could only speculate about the mechanisms of injury. ${ }^{15}$ Notably, the process of ischemia was not identified by the computed tomography scan performed in our case. An MRI scan is far more sensitive in excluding potential causes such as spinal cord compression, or detecting other causes such as spinal cord ischemia. . $^{3,11,16}$

There is no definitive treatment for spinal cord ischemia without cord compression. However, maintenance of spinal cord perfusion and oxygenation should be a clinical priority. Cerebrospinal fluid drainage is an often-used technique for prevention of spinal cord ischemia during aortic surgery. ${ }^{17}$ It has 
also been shown that cerebrospinal fluid drainage may contribute to reversal of neurological deficits following surgery. ${ }^{18,19}$ High-dose steroid treatment has been advocated, although there is no clear evidence that steroids prevent long-term neurological damage, and potentially serious side effects make this treatment controversial. ${ }^{20}$ Despite this controversy, we chose a short course of steroid therapy for this patient, as it was felt that the risk-benefit ratio of short-term therapy would be acceptable, given the sudden onset of the lesion and the extent of neurological deficit.

Paraplegia following thoracotomy has been attributed to spinal cord ischemia as a result of epidural anesthesia/analgesia. Possible mechanisms have been suggested ${ }^{16,21}$ none of which has been proven. In our case, spinal ischemia occurred in the absence of an epidural catheter or epidural injection. The MRI findings in were consistent with a mechanism of spinal cord ischemia secondary to occlusion/transection of the left T5-6 intercostal artery and/or its medullary branch supplying the cord. ${ }^{22}$ This mechanism is also supported by a level of ischemia which coincides with the level of the thoracotomy, and evidence of hemostatic material ("Surgicel", Ethicon®-Sarl, Neuchatel, Switzerland) in the left T4-5 neural foramen demonstrated by the MRI (Figure not presented). This region of the cord is known to be sensitive to ischemia due to its vascular anatomy. ${ }^{23}$

In conclusion, this case demonstrates that spinal cord injury may occur in thoracotomy patients in the absence of epidural anesthesia and epidural catheter placement, and in the absence of cord compression based upon MRI findings. We recommend routine assessment of the neurological status of patients following thoracotomy, with or without epidural anesthesia. An MRI of the thoracic spine should be performed in any case of neurological deterioration.

\section{References}

1 Kane RE. Neurologic deficits following epidural or spinal anesthesia. Anesth Analg 1981; 60: 150-61.

2 Attar S, Hankins JR, Turney SZ, Krasna MJ, McLaughlin JS. Paraplegia after thoracotomy: report of five cases and review of the literature. Ann Thorac Surg 1995; 59: 1410-5; discussion 1415-6.

3 Popat KU, Ngyugen T, Kowalski AM, Daley MD, Arens JF, Thakar D. Postoperative paraplegia after nonvascular thoracic surgery. Internet J Anesthesiol 2004; 8: 1 .

4 Lovstad RZ, Steen PA, Forsman M. Paraplegia after thoracotomy--not caused by the epidural catheter. Acta Anaesthesiol Scand 1999; 43: 230-2.

5 Wada E, Yonenobu K, Ebara S, Kuwahara O, Ono K. Epidural migration of hemostatic agents as a cause of postthoracotomy paraplegia. Report of two cases. J Neurosurg 1993; 78: 658-60.

6 Dogan S, Kocaeli H, Doygun M. Oxidised regenerated cellulose as a cause of paraplegia after thoracotomy: case report and review of the literature. Spinal Cord 2005 ; 43: 445-7.

7 Iwabuchi S, Koike K, Okabe T, Tago S, Murakami T. Iatrogenic paraplegia caused by surgicel used for hemostasis during a thoracotomy: report of a case. Surg Today 1997; 27: 969-70.

8 Wulf $H$. Epidural anaesthesia and spinal haematoma. Can J Anaesth 1996; 43: 1260-71.

9 Cheshire WP, Santos CC, Massey EW, Howard JF $J r$. Spinal cord infarction: etiology and outcome. Neurology 1996; 47: 321-30.

10 Bhuiyan MS, Mallick A, Parsloe M. Post-thoracotomy paraplegia coincident with epidural anaesthesia. Anaesthesia 1998; 53: 583-6.

11 Massad MG, Donahue PE, Rubeiz H, et al. Paraplegia after esophagectomy: who are the patients at risk? J Thorac Cardiovasc Surg 2001; 121: 386-8.

12 Brewer LA III, Fosburg RG, Mulder GA, Verska JJ. Spinal cord complications following surgery for coarctation of the aorta. A study of 66 cases. J Thorac Cardiovasc Surg 1972; 64: 368-81.

13 Konstantinidou AS, Balamoutsos NG. Paraplegia in a patient who by chance missed the insertion of an epidural catheter (Letter). Anesth Analg 1996; 82: 1110.

14 Bromage PR. Paraplegia in a patient who by chance missed the insertion of an epidural catheter (Letter). Anesth Analg 1996; 83: 1351.

15 Urquhart-Hay D. Paraplegia following epidural analgesia. Anaesthesia 1969; 24: 461-70.

16 Chan LL, Kumar AJ, Leeds NE, Forman AD. Post-epidural analgesia spinal cord infarction: MRI correlation. Acta Neurol Scand 2002; 105: 344-8.

17 Wan IY, Angelini GD, Bryan AJ, Ryder I, Underwood $M J$. Prevention of spinal cord ischaemia during descending thoracic and thoracoabdominal aortic surgery. Eur J Cardiothorac Surg 2001; 19: 203-13.

18 Blacker DJ, Wijdicks EF, Ramakrishna G. Resolution of severe paraplegia due to aortic dissection after CSF drainage. Neurology 2003; 61: 142-3.

19 Tiesenhausen K, Amann W, Koch G, Hausegger KA, Oberwalder $P$, Rigler $B$. Cerebrospinal fluid drainage to reverse paraplegia after endovascular thoracic aortic aneurysm repair. J Endovasc Ther 2000; 7: 132-5.

20 Hall ED, Springer JE. Neuroprotection and acute spinal cord injury: a reappraisal. NeuroRx 2004; 1: 80-100.

21 Skouen JS, Wainapel SF, Willock MM. Paraplegia following epidural anesthesia. A case report and a literature review. Acta Neurol Scand 1985; 72: 437-43. 
22 Shamji MF, Maziak DE, Shamji FM, Ginsberg RJ, Pon $R$. Circulation of the spinal cord: an important consideration for thoracic surgeons. Ann Thorac Surg 2003; 76: 315-21.

23 Thron AK. Vascular Anatomy of the Spinal Cord - Neuroradiological Investigations and Clinical Syndromes. New York: Springer-Verlag; 1988. 